\title{
Improvement of Community Governance to Support Slum Upgrading Programs in Indonesia
}

\author{
Asyrafinafilah Hasanawi ${ }^{1}$ \\ Bandung Institute of Technology - Indonesia \\ Hasanawi Masturi ${ }^{2}$ \\ University of Muhammadiyah Bengkulu - Indonesia \\ Adib Hasanawi ${ }^{3}$ \\ Bandung Institute of Technology - Indonesia
}

\begin{abstract}
Urbanism's impact creates land scarcity as a result of an imbalance in urban land between supply and demand. As a developing country, Indonesia is still striving to overcome the slum area and provide decent housing for low - income groups. In fact, the city is owned by everyone, so slum people and other low - income groups have the right to the city to enjoy the results of development and its facilities and infrastructure, including decent urban living spaces. These areas are government challenges and opportunities to provide the best housing services for poor or marginal communities. Over the past decades, slum upgrading has become a global solution to overcome slum problems. It relies on the concept of ' self - help 'in which community participation is used as a means of improving and sustaining the quality of life of slum dwellers. The number of researches was carried out to analyze the level of community participation in slum upgrading, but not many analyze the level of governance in slum upgrading. The purpose of this research is to analyze the performance of Indonesian governance in achieving successful slum upgrading by using a single case study of one of Indonesia's slum upgrading projects, namely the Neighborhood Upgrading and Shelter Sector Project (NUSSP). The transition from centralized to decentralized governance has become the biggest challenge in implementing slum upgrading in Indonesia, especially on issues of political engagement, coordination, and cooperation, financial sustainability, tenure security, continuity, and institutionalization. This research has led to the conclusion that transitional Indonesia requires a unified strategy that combines some forms of centralized governance with some forms of decentralized governance. Finally, the concepts of ' self - help, ' ' less governance, ' and ' development from below ' proposed as the original concepts of slum upgrading could not work independently. Strong intervention, adequate governance and ' development from above ' are really needed to achieve successful slum upgrades.
\end{abstract}

Keywords: slum, slum upgrading; governance; sustainability; community participation.

\footnotetext{
${ }^{1}$ Asyrafinafilah Hasanawi is researcher of Urban and Regional Planning Program Study. School of Architecture, Planning, and Policy Development. Bandung Institute of Technology. Email: filah@sappk.itb.ac.id.

${ }^{2}$ Hasanawi Masturi is lecturer at Department of Agricultural Economics/Agribusiness. Faculty of Agriculture. University of Muhammadiyah Bengkulu.Email: hasanawi@umb.ac.id

3 Adib Hasanawi is student at Environmental Engineering Program Study. Faculty of Civil and Environmental Engineering. Bandung Institute of Technology. Email: adib.hasanawi@students.itb.ac.id
} 


\section{Improvement of Community Governance to Support Slum Upgrading Programs in Indonesia}

Asyrafinafilah Hasanawi, Hasanawi Masturi, and Adib Hasanawi

\section{Introduction}

\subsection{Background of Problems}

Indonesia has been quickly urbanized from rural areas to urban areas and from smaller urban areas to more significant urban areas through high population growth and substantial urban development. In 2018, 4.2 billion people, 55 percent of the world's population, lived in cities. By 2050, the urban population is expected to reach 6.5 billion. Besides, cities occupy just 3 percent of the Earth's land but account for 60 to 80 percent of energy consumption and at least 70 percent of carbon emissions. In the coming decades, 90 percent of urban expansion will be in the developing world. Then, 828 million people are estimated to live in slums, and the number is rising (UNDP, 2019). This phenomenon has resulted in a growing demand for urban essential services, namely housing and basic infrastructure. Meanwhile, government incapacity to provide appropriate public housing particularly to low-income groups and institutional weaknesses to address urban poor aspirations that have created urban pockets of squatters and slum settlements. The efforts in the 1970 s to overcome slums by evacuation have proven not to produce satisfactory results, but to move poverty from one place to another.

The Slum Upgrading Program is a common way to improve the standard of lives of slum residents without 'bulldozing' them across many nations. This is considered an effective solution for several reasons: to reduce the possible trouble reactions of slum-residents, to reduce the economic cost of separating slumresidents from jobs and to prevent disturbing social or ethnic support structures (Werlin, 1999). There is increasing importance to the presence of slum upgrading since the UN-Habitat has mandated the Cities without slums (SDGs), a time-limited target for sustainable development, as well as continuing to implement the New Urban Agenda in "cities without slums." It promotes governments and stakeholders to reorient their strategies on slum enhancement and avoidance and to acknowledge that slums must be considered as a significant growth issue utilizing a unified worldwide, regional and urban policy and intervention (UN Habitat, 2018).

There is now increasing recognition of the significance of governance as the most crucial variables for achieving success in slum management. The ongoing development of urbanization and slum populations representing serious spatial fragmentation and financial inequalities have called for coherent and cooperative action between various stakeholder levels. Milbert (2006) claims that every effort to tackle the slum requires multi-level governance. Our study has gone beyond that. In implementing slum upgrading programs, it would be immensely helpful to analyze the governance performance that could properly contribute to the achievement of the program. This study uses one example of a slum upgrading project in Indonesia, a developing country which has a lengthy history of slum and different slum upgrading projects.

In the reign of democratization and decentralization, the question may arise: what works best to improve slums? The project to upgrade the slum is tensioned. The decentralized government can improve the immediate, broad community involvement in decision-making, as a means to better respond to residents ' objectives and demands in local strategies and projects. The UN-Habitat surveys 
demonstrated that the most stabilizing slum growth rates in countries where decentralization and the participation of citizens, like Brazil, Columbia, and Mexico, are strongly effective since 1990. On the other hands, countries like Egypt, Morocco, and Tunisia with highly centralized governance structures also appear to be successfully achieving their slum objective. In Morocco, for example, the housing ministry drives slum upgrade from the core and has delivered excellent outcomesfrom 1993 to 1999, 82 slum upgrading activities were carried out to almost 99,000 homes (UN Habitat, 2006).

The slum characteristics currently shift from homogenous to heterogeneous composition; including mixed planned and unplanned patterns, mixed formal and informal sectors, and combined economic and residential functions. The method and specific formes of governance and relationships that will involve this hybridization will be more creative and comprehensive (Nijman, 2009). Therefore, it is very important for slum upgrading to link the two cornerstones of the governance, bottom-up and top-down decision-making structures. In all slum upgrading initiatives (Durand 2006) a coherent national and municipal governance approach, a suitable and consistent national and regional legal and regulatory structure, economic assets and the suitable mobilizing mechanism, political will and continuity are needed.

Indonesia is among countries which have practiced slum upgrading programs for almost five decades and had experienced a considerably successful slum upgrading, known as Kampung Improvement Program (KIP) which was initiated in 1969. However, many problems followed this former slum upgrading program after its peak performance in the 1970s, covering aspects on land tenure, political will, funding, and management by community participation. These problems have made the results of the program unsustainable (Werlin, 1999).

In 2001 Indonesia began a process of decentralization after reforming the democratic system in 1998, in an attempt to give more political and financial influence to local governments. The Neighborhood upgrading and shelter project (NUSSP) was launched during this period. It is part of the program to reduce poverty which is eligible for the Asian Development Fund (soft loan), which aims to raise the standard of living of 2 million slums in 30-40 municipalities in Indonesia, by upgrading 5,000 ha of degraded housing areas (the Ministry of Public Works, "Efforts to Improve the Quality of Slum Settlements", 2003).

The difference between NUSSP and the former slum upgrading program, namely KIP, is that NUSSP is more holistic than KIP (NUSSP, 2007). KIP activities were dominated by three infrastructure improvements: paved access roads, bridges, and footpaths; water supply, sanitation, and drainage canals; schools and health clinics. Meanwhile, NUSSP combined four interrelated components: (1) improved planning and management system to upgrade sites and establish new ones for the urban poor; (2) improved access to shelter finance by the poor through central financial institutions and local financial institutions or their branches; (3) upgrading of poor neighborhoods and develop new sites for the poor; and (4) strengthened sector institutions to deliver the program. The other difference is that KIP was executed fully by the national government (centralized system) and targeted only on few big cities such as Jakarta, Surabaya, and Denpasar, while NUSSP was executed by the local government with support and direction from the national government (decentralized system) and targeted on all cities or towns in Indonesia that face serious slum problems. 


\subsection{The Research Problems}

Slum upgrading practices and achievements in almost all parts of the world in general vary significantly overtime among countries and within cities. However, there appears to be a pattern: there is a strong correlation between the performance of governance and the success of slum upgrading program. Success in the slum upgrading program means that the positive outcomes or results of the program can be sustained and the growth of slum population can be diminished. The stronger political commitment in slum improvement the national and local governments have, the more significant the progress in reducing the growth of slums is. Along with the completion of the latest slum upgrading program in Indonesia, which is conceptually much better than the previous one, some questions remain: How did this new generation of slum upgrading perform in reality? Would this relatively comprehensive slum upgrading be successful enough? Reflected from this, I am interested in seeing how the process of governance which includes the interaction among multilevel stakeholders contributes to the success of current slum upgrading projects in Indonesia. Therefore, the main objective of this research is to analyze the performance of Indonesian governance in achieving the success in slum improvement and sustaining the results of slum upgrading program by evaluating the complete progress of one recent slum upgrading implementation in Indonesia.

\subsection{Logical Framework}

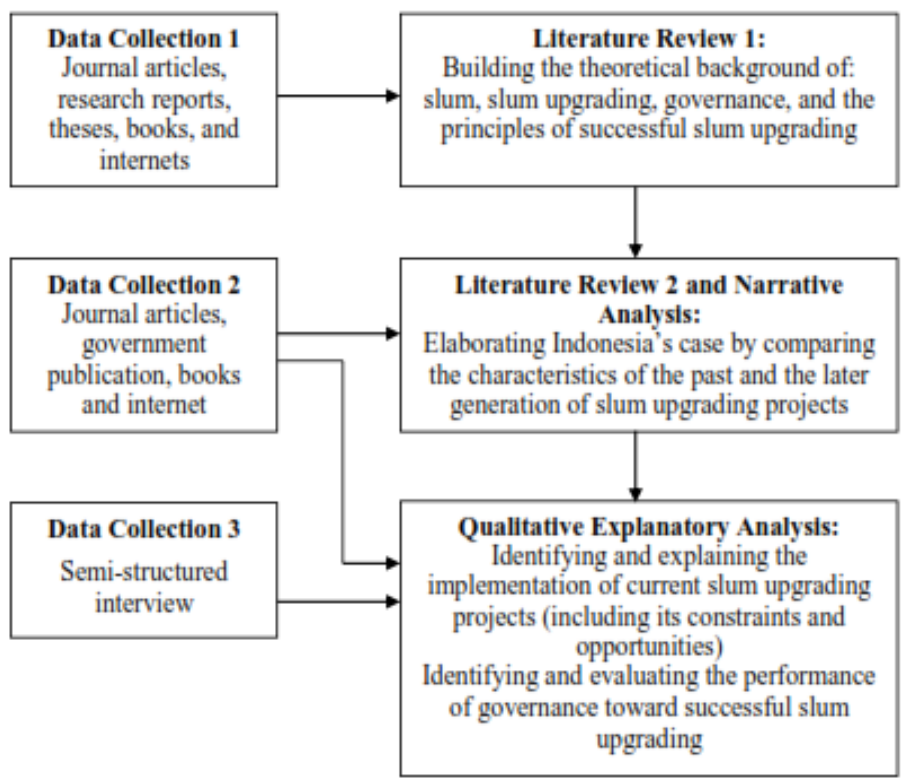

Figure 1. Research Methodology

\section{Literature Review}

"Slum" can be defined and perceived in a world that evolves over time. In the 1820 s it acquired its first idea, because in London the homes that had very bad conditions in terms of its characteristics, hygiene and safety could not be identified. The slum is perceptible as a heavily crowded, down-hill, poor and socially disruptive, generally industrial zone.' A shelter for small events, such as felony, vice, substance violence and metropolitan epidemics (UN Habitat, 2003). The definition also 
comprises conventional meanings -i.e.: "...housing areas that were once respectable or even desirable, but which have since deteriorated as the original dwellers have moved to new and better areas of the cities. The condition of the old houses has then declined, and the units have been progressively subdivided and rented out to lowerincome groups." (UN Habitat, 2003, p.9).

The characteristics of the slum vary from country to country, along with the concept. The reason is that slums are multidimensional and vibrant in existence. In specific, socio-economic and cultural conditions may influence the distinctions of slum features between nations. Seven features of slum were identified by the Indonesian Ministry: (1) minimum building type which meets safety and social living standards; (2) extremely thick building which is not risky to burn; (3) lack of water supply; (4) poor energy production and restricted power supply; (5) poor air plant; (6) poor and insufficient roads; and (7) restricted latrines.

Slum residents and activities are also varied and dynamic. Many kinds of literature have defined the dynamic shift from homogeneity to heterogeneity, enabling the development of complicated cities ' micro-spaces (see Nijman, 2009; Salim, 1998; Jellinek, 1995; Boswell, 1977). In the initial stages, slum societies were comprised of persons from the same racial groups, comparable backgrounds, and concentrations of skills, who had the same kind of employment (generally employment) and no cultural ties (Boswell 1977). Slum communities today consist of individuals from various ethnic groups, educational backgrounds, and skills, various types of jobs, from informal sector workers to formal sectors (servants, professions and teachers) with varying levels of income (Salim, 1998; Jellinek, 1995).

It is essential to know the origin of the slum formation before we address planning and public policies intended to tackle the slum. Slum and human settlement public policy as two ends of a coin. On one hand, the rise of the slum is not only an expression of the rapid increase and urbanization of the population, but it can also be seen as a consequence of the inability of housing strategies, legislation and delivering schemes, domestic and municipal policy and system governance. On the other hand, the slum can only be efficiently and sustainably tackled by stronger public policy and government.

There can be no urbanization in any country. Rapid urbanization always leads to migration from the countryside to the city, from tiny towns to large towns and there is continuous natural population growth. More than half the world's inhabitants live in metropolitan regions and more than $90 \%$ of this urban development takes place in emerging nations according to the Cities Alliance reports. There are two main factors behind this rapid urban migration: The pushing factors of migration that pushed out of people from their place of origin and The pulling factors of migration such as the new place which provides better opportunities for living.

Bad governance is another justification for why slums evolve. In response to urbanization phenomena, the Cities Alliance states that there are certain inappropriate behaviors of the government to response the slum. First, governments often neglect to acknowledge and include the rights of low-income communities in urban planning and thus contribute to the slum's development. According to Giok (2007), squatter and slum settlements have been created largely due to the city's reluctance to schedule and provide affordable housing for urban low-income groups. The low-income urban population, therefore, regards squatter and slum housing as the accommodation alternative. Secondly, urban resettlement occurs quicker than 
the attempts of the government to conform to it. There may be an absence of information on migrants and poor citizenship registration regulations.

For the following fifty years, governments have attempted to tackle slums by pushing them back from the cities and destroying them. Elimination or demolition has been selected to be an overall option for slum abolition. This reminds us of the rationality of technology in planning, which should be accomplished by procedural methods once the aims have been established. The purposes and resources are strongly connected (Allmendinger, 2002).

There have also been substantial transformations in public policy in the area of accommodation and residence. The slum problem has been influenced by the differences between urban and rural areas. At the first United Nations Conference on Human Settlements (Habitat I) the issue attracted worldwide exposure up to now.

The slum is a manifestation of the fast development, explosion in population and planning as well as public policy less sensitive to these phenomena. The characteristic slum types are increasing in a vibrant and heterogeneous manner, as these comprise of the vibrant, creative, comprehensively co-operated, vibrant (room), cultural (slum group) and financial aspects (their financial activity). Slum upgrading is regarded to be the finest option to meet all these needs. The upgrading of the slums depends on self-confidence and involvement in society to improve their working conditions.

\section{Methods/Methodology}

There are generally three primary study tasks: information compilation, literature assessment, and qualitative assessment. Data collection and literature review are concurrently carried out in Indonesia to establish a theoretical foundation for slum, slum upgrading, and achievement in the upgrading of slum areas. The information is gathered using two techniques: secondary and semi-structured information compilation. Qualitative analysis, meanwhile, is broken up into two techniques: narrative analysis and explanation assessment.

\section{Results, Analysis, and Discussions}

The Neighborhood Upgrading and Shelter Sector Project (NUSSP) is one of the Indonesian slum upgrade initiatives funded over a five-year term (2004-2009) by combined borrowing from global funds and public financing. The project seeks specifically to enhance accommodation and the atmosphere in slum neighborhoods for low-income groups, by providing funds for local authorities that collaborate with societies and personal groups, by facilitating low-income groups in building and upgrading indigenous homes through residential micro-credits, and to enhance the capacity of local government and communities in preparing participatory planning which focuses on harmonious division on roles and responsibilities between the government, private parties, and the community (the Ministry of Public Works, 2009). NUSSP was born out of the Indonesian Government's initiative to tackle the problem of slums in Indonesia and to speed up the achievement of the SDGs, in particular slum improvement targets.

Based on the background of the slum improvement in Indonesia, a number of slum rehabilitation and misery reduction programs were implemented in distinct ways. The Kampung Improvement Program (KIP) and Urban Poverty Project $(\mathrm{P} 2 \mathrm{KP})$ are two of those which are quite prominent. They all contributed significantly to slum performance in Indonesia's reduction and improvement. Much can be learnt from the experiences of these two programs, which cover both positive 
lessons and negatives to be learned in future in order to improve the slum. The following chart summarizes the valuable classes of those two programs:

Table 1. Three Generation of Slum Improvement in Indonesia

\begin{tabular}{|c|c|c|c|}
\hline $\begin{array}{c}\text { The } \\
\text { Evolution of } \\
\text { Slum } \\
\text { Improvement }\end{array}$ & $\begin{array}{c}\text { The } 1^{\text {st }} \text { Generation } \\
1960 s-1980 s\end{array}$ & $\begin{array}{c}\text { The } 2^{\text {nd }} \text { Generation } \\
\text { 1980s - 1990s }\end{array}$ & $\begin{array}{c}\text { The } 3^{\text {rd }} \text { Generation } \\
1990 \text { - now }\end{array}$ \\
\hline Program & $\begin{array}{l}\text { Kampong } \\
\text { Improvement } \\
\text { Program / KIP II and } \\
2 \text {, Sites-and-Services } \\
\text { Project }\end{array}$ & $\begin{array}{l}\text { Community-Based } \\
\text { Housing } \\
\text { Development/ } \\
\text { P2BPK }\end{array}$ & $\begin{array}{l}\text { Urban Poverty } \\
\text { Project/ P2KPm KIP } \\
\text { III, NUSSP }\end{array}$ \\
\hline Approach & $\begin{array}{l}\text { Market-driven, } \\
\text { supply-driven }\end{array}$ & $\begin{array}{l}\text { Participatory, } \\
\text { demand-driven }\end{array}$ & $\begin{array}{l}\text { Sustainable } \\
\text { development }\end{array}$ \\
\hline Focus & $\begin{array}{l}\text { Physical } \\
\text { improvement }\end{array}$ & $\begin{array}{l}\text { Community } \\
\text { participation }\end{array}$ & $\begin{array}{l}\text { Tridaya: } \\
\text { environmental, social, } \\
\text { and economic } \\
\text { development }\end{array}$ \\
\hline Key actors & $\begin{array}{l}\text { Government and } \\
\text { developer }\end{array}$ & $\begin{array}{l}\text { Communities and } \\
\text { NGOs }\end{array}$ & $\begin{array}{l}\text { Government, } \\
\text { communities, NGOs, } \\
\text { and private sectors }\end{array}$ \\
\hline Strengths & $\begin{array}{l}\text { - } \\
\text { infrastructure, } \\
\text { but also health } \\
\text { and education } \\
\text { facilities } \\
\text { Giving security } \\
\text { of tenure } \\
\text { Increasing land } \\
\text { price }\end{array}$ & $\begin{array}{ll}- & \text { Concern with } \\
\text { communities } \\
\text { participatory } \\
\text { - } \\
\text { Communities } \\
\text { have wide range } \\
\text { of activities } \\
\text { Giving access to } \\
\text { affordable } \\
\text { housing }\end{array}$ & $\begin{array}{l}\text { - Comprehensive } \\
\text { aspect is improved } \\
\text { Communities are } \\
\text { free to choose } \\
\text { component } \\
\text { activities } \\
\text { Communities } \\
\text { organization are } \\
\text { allowed to sustain } \\
\text { capital }\end{array}$ \\
\hline Weekness & 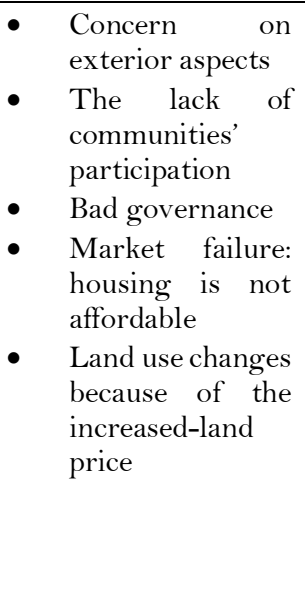 & 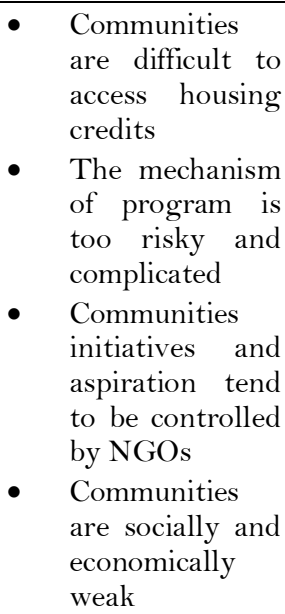 & $\begin{array}{l}\text { - Target is general, } \\
\text { not only for slum } \\
\text { dwellers } \\
\text { - The program } \\
\text { dominated by } \\
\text { social economic } \\
\text { development } \\
\text { Complex } \\
\text { relationship } \\
\text { among actors }\end{array}$ \\
\hline
\end{tabular}

Source: Juliman et al, 2006; Werling, 1999; Sumarto, 2009, P2KP, 2010)

The element of NUSSP is enhanced access by core and local economic organizations to housing financing for the needy. The plan aimed to create local financial institutions in the town or district to finance the housing industry through an in-house loan system and residential system for low-income groups, LembagaKeuangan Lokal-LKL. This is the element of the initiative. NUSSP's fifth element is 
to upgrade bad neighborhoods and to develop fresh locations for the needy. This element supports upgrading bad neighborhoods by building fresh facilities or rebuilding existing bad facilities and developing new sites for low income families. Strengthening industry organizations to enhance services is the last element of the NUSSP. This element involves a variety of capability construction operations, including space preparation and refuge creation for local authorities, local economic organizations and civil society, funding of housing for the needy, upgrading and creation of space for the needy and the creation of self-help organizations. This element is essential in the decentralizing age of slum upgrading. The NUSSP includes multi-stakeholders, coming from public institutions, personal groups and public organizations, from distinct sector and concentrations.

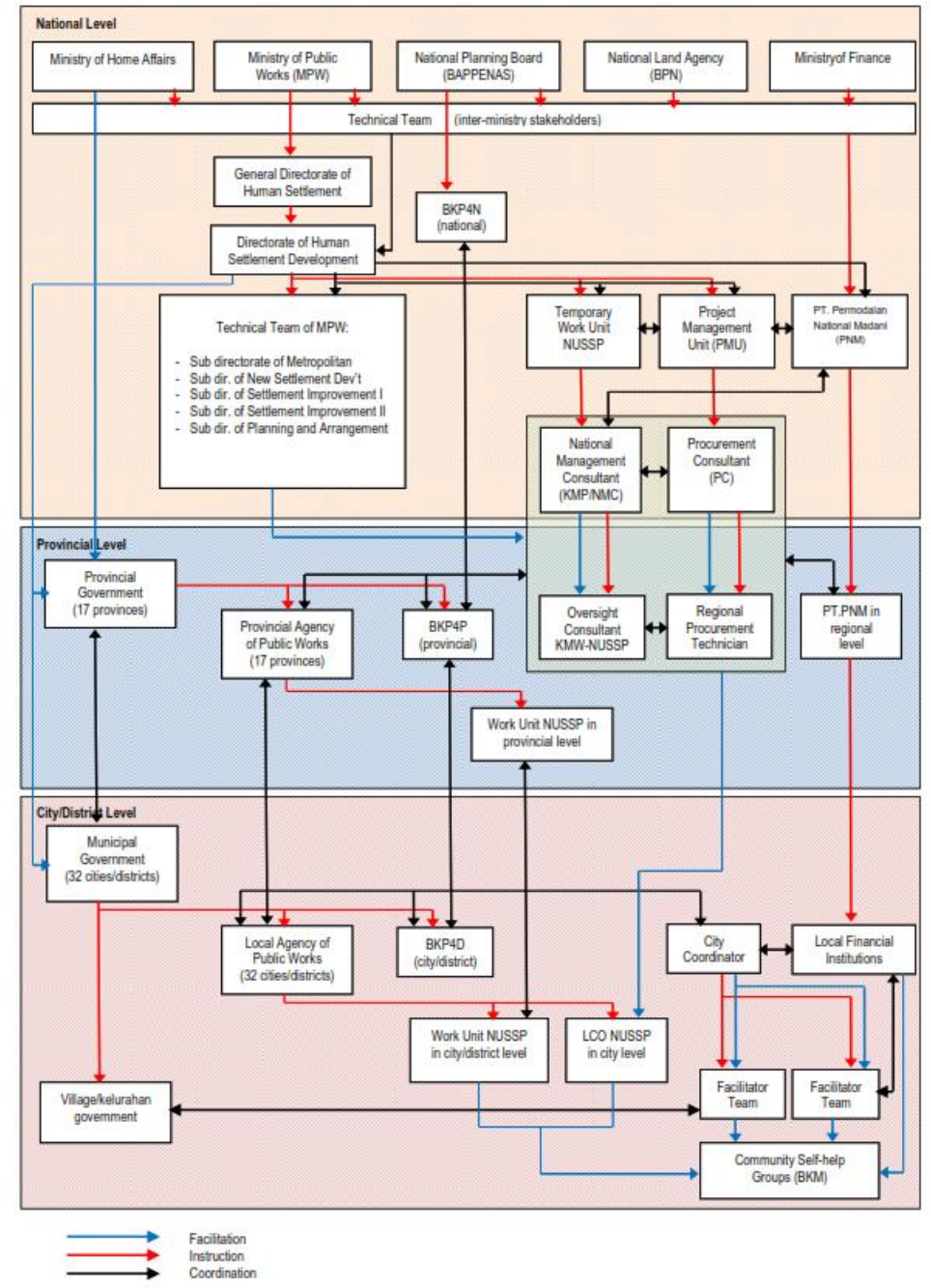

Figure 2. The Structure of NUSSP

Basically the acceptance of slum in Indonesia has been stated explicitly in the supreme legal basis of national ideology namely Pancasila and the 1945 Constitution of the Republic of Indonesia which upholds the right of poor society for decent, 
healthy, and affordable housing to achieve social justice for all. Then this highest legal basis is also translated into the law of spatial planning, the law of housing and settlement, the law of human rights, and the law of basic agrarian regulation. All these laws reassert the rights of the poor to obtain decent housing and healthy environment and support efforts to improve the quality of slum.
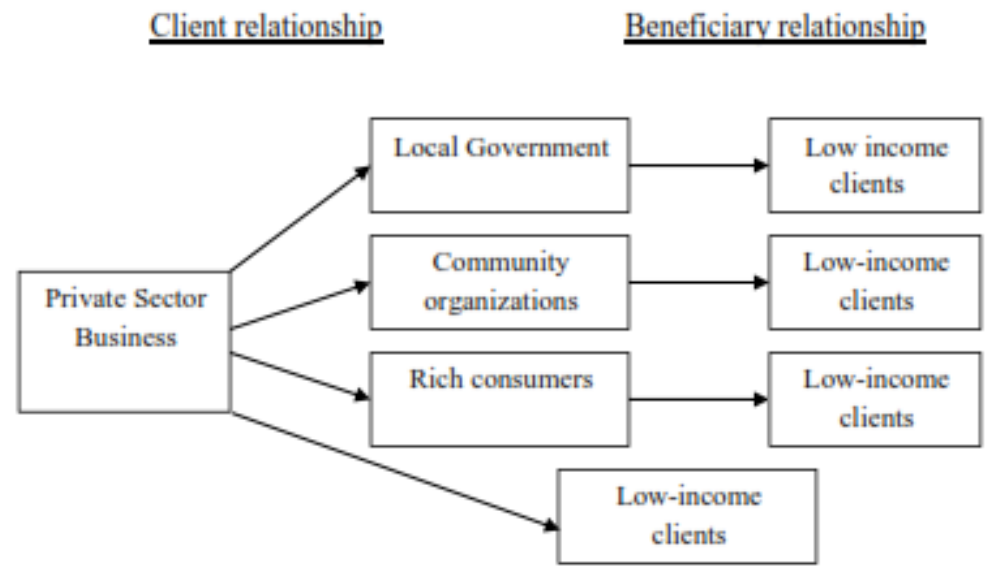

Figure 3. Approach to Slum Dwellers Participation in Slum Upgrading Source: Baker, 2008

These links include patron-beneficiary relationships, political accountability relationships, regulatory relationships, and donor accountability relationships which connect each of these clients to poor people themselves, and can shape private sectors incentives, investments, service quality, and other business decisions. This multiplicity of potential connections creates a diverse universe of potential privatepublic-individual partnerships.

\section{Conclussion and Recommendation}

\subsection{Conclusion}

Based on the historical development of slum upgrading in Indonesia, the slum upgrading approach that is too oriented to the intervention of the government or market cannot work effectively. Each thought has advantages as well as weaknesses. On the one hand, the management of slum upgrading which is dominated by the government actors is less able to generate community involvement to maintain the results of slum upgrading because of the lack of sensitivity to local needs and priorities and vulnerable to corruption practices. The involvement of private party which actually has both financial and managerial potency is also limited. On the other hand, the management of slum upgrading which is controlled by market forces will encourage unevenness in growth and development because housing for the poor is considered as an economic commodity and has a weak position in urban land competition. In addition, if slum upgrading just relies on community participation it would be impossible because most slum dwellers are the poor who do not have much choice. Through the implementation of various slum upgrading programs in Indonesia, starting from the first until the latest generation, it can be proven that the concept of 'freedom to build' as the original concept of slum upgrading, promoted by Turner school (1972), cannot work independently. Intervention from governments and private parties are still necessary and required to be implemented 
jointly with community participation. Nevertheless, to what extent the ideal intervention of each actor is still on a big question.

\subsection{Recommendation}

1. For slum upgrading projects

- Slums are perceived to be temporary due to their illegal status. From our analysis, we see that slums are anything but temporary and keep growing.

- The mechanisms for achieving effective public participation can be complicated and time consuming (Dupont et al., 2014; Rigon, 2014; Samad, 2006). Some strategic characteristics of the $3^{\text {rd }}$ generation of slum upgrading in Indonesia can be enumerated and may be transferrable to other cases where top-down/bottom-up collaboration is necessary.

- Taking local engagement as a prerequisite for successful slum upgrading.

2. For the study and analysis of slums in future

- In order to carry out the a fore mentioned guidelines effectively, our knowledge of slums should not be restricted to household data and numbers. warrants a better understanding of slums and to achieve this, the following recommendations have been drawn up.

\section{References}

Aitken, S.C. 2005. "Textual Analysis: Reading Culture and Context". In Methods in Human Geography: a Guide for Students Doing a Research Project, 2nd edition, Ed. Robin Flowerdew and David Martin, 233-249. England: Pearson Education Limited.

Allmendinger, P. 2002. Planning Theoy. New York: Palgrave. Antara News. About 18 Percent of Indonesian Population is Living in Urban Slums.

Arnott, R. 2008. Housing Policy in Developing Countries The Importance of the Informal Econom. http://economics.ucr.edu/papers/papers08/08-01.pdf.

Baker, J.L and McClain, K. 2008. Private Sector Involvement in Slum Upgrading. Global Urban Development Magazine 4(2). http://www.globalurban.org/GUDMag08Vol4Iss2/BakerMcClain.htm.

Boswell, D. 1977. "Social Segregation and the Slums". In The City as Social System. London: The Open University Press.

Bunsha, D. 2005. On the Highroad to Shanghai. Frontline 22(16): 22-25. Centre on Housing Rights and Evictions. Human Rights and Slum Upgrading: General Introduction and Compilation of Case Studies. COHRE, http://www.cohre.org/store/attachments/Slum\%20upgrading\%20and\%20 human\%20rights.pdf

Cities Alliance. About Slum Upgrading. Cities Alliance. http://www.citiesalliance.org/ca/About-slum-upgrading. City of Vancouver. Social Planning Initiatives and Policy Work. City of Vancouver. http://vancouver.ca/commsvcs/socialplanning/initiatives/index.htm

Cities Alliance. About Slum Upgrading. Cities Alliance. http://www.citiesalliance.org/ca/About-slum-upgrading.

City of Vancouver. Social Planning Initiatives and Policy Work. City of Vancouver. http://vancouver.ca/commsvcs/socialplanning/initiatives/index.htm

Commission on Global Governance. 1994. Our Global Neighbourhood. London: Oxford.

Cotton, A. and Skinner, R. 1989. Barrier to Resident Participation in Slum Improvement: The Maintenance Question, Community Development Journal, 25(1): 37-41, http://cdj.oxfordjournals.org/cgi/reprint/25/1/37 
Asyrafinafilah Hasanawi, Hasanawi Masturi, and Adib Hasanawi

Crang, M. 2005. "Analysing Qualitative Materials". In Methods in Human Geography:a Guide for Students Doing a Research Project, 2nd edition, Ed. Robin Flowerdew and David Martin, 218-232. England: Pearson Education Limited.

Davidoff, P. 1965. "Advocacy and Pluralism in Planning". In Readings in Planning Theory, 2nd edition. Ed. Scott Campbell and Susan S. Fainstein, 2 10-223. UK: Blackwell Publishing Ltd.

Davis, M. 2006. Planet of Slums. New York: Verso. Decree of Minister of Finance Republic Indonesia No.35/KMK.07/2003 on Planning, Impelementation/Administration, and Monitoring of Foreign Loans to Local Governments.

Durand, A. 2006. Informal Settlements and the Millenium Development Goals: Global Policy Debates on Property Ownership and Security of Tenure. Global Urban Development 2(1) : 1-15 (March 2006). http://www.globalurban.org/GUDMag06Vol2Iss 1/Durand-Lasserve.htm

European Comission. 1997. The EU Compendium of Spatial Planning Systems and Policies. Luxembourg, Regional Development Studies.

Firman, T. 1997. Land Conversion and Urban Developmentin the Northern Region of West Java, Indonesia. Urban Studies, 34: 1027-1046.

Giok, L.O and Kai, H.P. 2007. Urbanization and Slum Formation. Journal of Urban Health 84(5): 27-34.

Hauser, P.M, Gardner, R.W, Laquiem, A.A, and El-Shakhs, S. 1982. Population and the Urban Future. Albany, New York: Suny Press.

Healey, P. 1995. "The Communicative Turn in Planning Theory and Its Implications for Spatial Strategy Formation”. In Readings in Planning Theory, 2nd edition. Ed.

Scott Campbell and Susan S. Fainstein, 237-253. UK: Blackwell Publishing Ltd. Healey, P. 1997. Collaborative Planning: Shaping Places in Fragmented Societies. London: MacMillan Press.

Hudalah, D. 2006. Institution, Culture and Neo-Liberalism: Reshaping Planning System in the Transitional Indonesia. Master Thesis, Rijks Universiteit of Groningen - Bandung Institute of Technology.

Lloyd, P. 1979. Slums of Hope? Shanty Towns of the Third World. Manchester: Manchester University Press.

Milbert, I. 2006. Slums, Slum Dwellers, and Multilevel Governance. The European Journal of Development Research 18(2) : 299-318.

Ministry of Public Works. 2006. General Guidelines NUSSP: Enhancing Empowerment, Solving Urban Slums. Jakarta: Ministry of Public Works.

Ministry of Public Works. 2009. NUSSP 2005-2009: Developing Pillars of Hope. Jakarta: Ministry of Public Works.

Ministry of Public Works. 2009. The Draft of Housing and Settlement Act (revision on Law No.4 on Housing and Settlement of 1992). Jakarta: Ministry of Public Works.

Ministry of Public Works. 2009. Memorandum of Understanding between the Asian Development Bank and the Government of Indonesia: Loans 2072/2073INO

Neighborhood Upgrading and Shelter Sector Project.

Mukhija, Vinit. 2001. Enabling Slum Redevelopment in Mumbai: Policy Paradox in Practice. Housing Studies 16(6): 791-806.

Nijman, J. 2009. A Study of Space in Mumbai's Slum. Journal of Economic and Social Geography 101(1): 4-17. 
NUSSP. NUSSP: The Challenge of Decentralization (22-6-2007). NUSSP. http://www.nussp.or.id/tulisandetil.asp? $\operatorname{mid}=221 \& \mathrm{catid}=2 \&$

Salim, E. 1998. "Perkampungan Kota dan Lingkungan". In Sejumlah Masalah Permukiman Kota, Eko Budiharjo. Bandung: Alumni Bandung.

Silver, C. 2008. Planning the Megacity: Jakarta in Twentieth Century. New York: Routledge.

Struyk, R. J., Hoffman, M. L. and Katsura, H. M. 1990. The Market for Shelter in Indonesian Cities. Washington, DC: Urban Institute.

Sumarto, H.S. 2009. Inovasi, Partisipasi, dan Good Governance: 20 Prakarsa Inovatif dan Partisipatif di Indonesia. Jakarta: Yayasan Obor Indonesia.

Valentine, G. 2005. "Tell me about...: Using Interviews as a Research Methodology". In Methods in Human Geography: a Guide for Students Doing a Research Project, 2nd edition. Ed. Robin Flowerdew and David Martin, 110-127. England: Pearson Education Limited.

Werlin, H. 1999. the Slum Upgrading Myth. Urban Studies, 36(9): 1523-1534 http://usj.sagepub.com/content/36/9/1523 (accessed February 4, 2010).

Winarso, H. 2002. Land and Housing Policy for Residential Land Development in Indonesia. Working Paper No: WP-02-002. Bandung: Institute of Technology Bandung. 